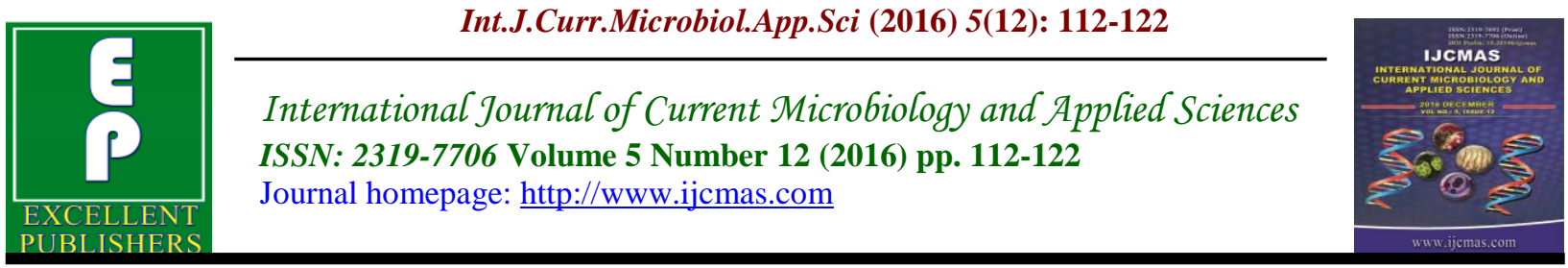

Original Research Article

http://dx.doi.org/10.20546/ijcmas.2016.512.013

\title{
Antifungal Activity of Local Microbial Isolates against Snap Bean Pathogens
}

\author{
Alex M. Fulano ${ }^{1 *}$, James W. Muthomi ${ }^{1}$, John M. Wagacha ${ }^{2}$ and \\ Agnes W. Mwang'ombe ${ }^{1}$ \\ ${ }^{1}$ Department of Plant Science and Crop Protection, Kenya \\ ${ }^{2}$ School of Biological Sciences, University of Nairobi, P. O. Box 30197, 0100 \\ GPO, Nairobi, Kenya \\ *Corresponding author
}

\section{Ke y words}

Antifungal activity, biopesticides, microbial antagonists, snap beans.

\section{Article Info}

Accepted:

08 November 2016

Available Online:

10 December 2016

\section{A B S T R A C T}

Production of snap beans is constrained by diseases that make farmers use synthetic pesticides excessively. Use of synthetic pesticides leads to contamination of produce, threat to beneficial organisms and pollutes the environment. Microbial pesticides are eco-friendly, target-pest specific, biodegradable and safe hence alternative to synthetic pesticides. In vitro studies were conducted to evaluate the antifungal activity of microorganisms isolated from local environment. Test plant pathogens were isolated from diseased tissues and antifungal activity of the microbial antagonists evaluated against species of Fusarium, Colletotrichum, Alternaria and Rhizoctonia using the dual culture method. Growth inhibition was determined as reduction in plant pathogen colony diameter. A total of 42 microbial isolates were found to possess antimicrobial activity out of which 16 were most active. The most efficacious antagonists were identified as Trichoderma viride, $T$. harzanium, T. asperellum and Paecilomyces. T. harzianum was the most active and inhibited the test pathogens by up to $66 \%$. The results indicated that local soils, rhizosphere and dead organic substrates are potential sources of microbial antagonists that can be exploited. These microbial biopesticides would serve as alternatives to synthetic pesticides in management of diseases in snap beans.

\section{Introduction}

Small holder farmers of snap beans face the constraint of diseases that affect the crop from planting to harvesting. These diseases range from root rots, wilts, stem rots, blights, leaf spots, mildews and rusts. The notable causal agents of these diseases include species of Alternaria, Rhizoctonia, Fusarium, Colletotrichum and Phaeoisariopsis (Infonet-Biovision, 2016). These economically important pathogens of snap beans lead to low yields and further damage market preferred pod quality characteristics (Mohammed, 2013; Mulanya, 2014; Nyasetia, 2011). Frequent use of synthetic pesticides in managing diseases in snap beans is unsustainable as they are hazardous to non-target organisms, pollutes the environment, lead to resistance by pathogens against fungicides and lead to chemical residues above recommended levels on pods which lead to interception and rejection of produce at export markets 
(Fening et al., 2014; Nyasetia, 2011; Ouma et al., 2014). The strict maximum residue level (MRLs) requirements have resulted into low volumes of snap beans designated for export market because smallholder farmers need to invest heavily and still fear being non-compliant (Ouma et al., 2014). Therefore, use of locally developed microbial biopesticides is an alternative to synthetic pesticides in management of crop diseases (Belete et al., 2015; Srinivasan, 2012).

Use of biopesticides has gained popularity all over the world and formulations are available in market as one of the alternatives of disease management (Chandler et al., 2011; Ouma et al., 2014; Srinivasan, 2012). In Kenya commercial formulated biopesticides are of foreign origin that makes them expensive hence limiting their use by smallholder farmers. The attributes that make biopesticides to be best alternatives to synthetic pesticides include having no toxic residues, are harmless to beneficial organisms and pose minimal risk to the environment and humans, are effective as the synthetic pesticides in managing diseases and have high compatibility with other pest management techniques (Chandler et al., 2011; Ouma et al., 2014; Sola et al., 2014). Many species of antagonistic microorganisms inhibit mycelia growth of plant pathogens in in vitro bioassays (Belete et al., 2015; Figueirêdo et al., 2010; Omar and Ahmed, 2014).This implies that with relevant technology for mass multiplication and formulation, the adoption of local microbial biopesticides is relatively cheap and safer to producers, consumers and environment. The stringent requirements during snap beans marketing are remediated by use of biopesticides that present premium value snap beans on niche markets that will enable the smallholder farmers' worth in investing in snap bean production (Kimani, 2014; Ouma et al., 2014).This study evaluated activity of antagonistic microorganisms isolated from local environments in reducing the growth of plant pathogenic fungi in vitro.

\section{Materials and Methods}

\section{Isolation of antagonistic microorganisms}

Microorganisms were collected from the rhizosphere in cultivated fields and pasture land, roots, cattle shed, decaying wood and decomposing organic matter. Soils were taken at a depth of $10 \mathrm{~cm}$ and air-dried for seven days by spreading on surface sterilized bench. Microorganisms from soil and compost were isolated by serial dilution (Belete et al., 2015). Ten grams of each composite soil sample was suspended in 100 $\mathrm{ml}$ sterile distilled water to obtain a suspension that was serially diluted. One millilitre aliquot of each of $10^{-2}, 10^{-3}$ and $10^{-}$ ${ }^{4}$ dilutions was pipetted into plates that were later inoculated with $20 \mathrm{ml}$ Nutrient Agar (NA) and in triplicate. The suspension and molten media in the plates were thoroughly mixed by swirling in a gentle manner to uniformly spread the suspension under aseptic conditions.

The isolation of microorganisms from roots and decaying woods was by direct plating. The decaying pieces of wood were washed with $70 \%$ alcohol for five minutes and then cut into $3 \mathrm{~mm}$ blocks. Three pieces of wood were direct plated in molten PDA and NA. Incubation of bacterial cultures was for 48 hours with Petri plates in inverted position under room temperature $\left(23 \pm 2{ }^{\circ} \mathrm{C}\right)$. Fungal and actinomycetous cultures were incubated for seven days under room temperature (23 $\pm 2{ }^{\circ} \mathrm{C}$ ). After incubation, microorganisms showing clear zones of inhibition against other microorganisms were sub-cultured and purified on PDA for fungi and 
actinomycetes, and bacteria on NA. Purified cultures of bacteria were inoculated on sucrose-peptone agar slants while the fungi and actinomycetes were maintained on PDA slants at $4^{\circ} \mathrm{C}$.

\section{Isolation of plant pathogenic fungi}

Fungal plant pathogens were isolated from diseased roots, stems, leaves and pods of snap beans by direct plating. The diseased tissues were first washed in running water to remove surface soil, dust and other contaminants. Small pieces measuring $3 \mathrm{~mm}$ in length of plant tissues were cut using sterile surgical blade and then surface sterilized in $1.3 \%$ sodium hypochlorite for two minutes. The plant tissues were rinsed three times in sterile distilled water and then blot dried using sterile absorbent paper. Four pieces were aseptically direct plated on PDA media and incubated for seven days. Subculturing was done by aseptically cutting small pieces of mycelia at edges of colonies and transferring to new PDA media to make pure cultures (Siameto et al., 2010).

\section{Screening and evaluation of microbial antagonists}

Fusarium solani, Colletotrichum lindemuthianum and Rhizoctonia solani were used as test pathogens in screening of microbial isolates for antifungal activity. The agar discs having the antagonist microorganism were aseptically inoculated at four equidistant positions on PDA. Discs having six days old cultures of each plant pathogenic fungus were inoculated at the centre of the cultured plates. The control plates included test pathogens inoculated alone at the centre and the experiment was replicated three times. The plates were incubated at room temperature $\left(23 \pm 2{ }^{\circ} \mathrm{C}\right)$ to allow adequate antagonist-pathogen interaction to take place. The plates were arranged in a completely randomized design.
Data was collected 9 days after inoculation (DAI) on PDA media by recording the growth diameters of the pathogens in millimetres. Colony diameters of the fungal pathogens in the test and control plates were measured and recorded. The colony diameter was given as the mean of two perpendicular diameters. The data was used to obtain the inhibition in the mycelia growth of three test pathogens by the potential antagonist microbial isolates. The antifungal activity was determined by measuring the pathogen colony diameters and percentage inhibition calculated according to Silliman et al. (2015):

Percentageinhibition $=\frac{\mathrm{A}-\mathrm{B}}{\mathrm{A}} \times 100$

Where $\mathrm{A}$ is the diameter of mycelia growth of pathogenic fungus in control and $\mathrm{B}$ is the diameter of mycelia growth of pathogenic fungus with antagonist.

The percentage of growth inhibition of each test pathogen by potential microorganism isolates was calculated and average percentage growth inhibition was used in rating effectiveness of isolates. Potential antagonistic microorganism isolates were categorized as effective in inhibiting radial growth of test pathogens by giving them a score as per modified Bogumił et al. (2013). Where; 1 - Low antagonistic activity (I < 51\%), 2 - Moderate antagonistic activity (I $=51-59 \%), 3-$ High antagonistic activity (I $=60-75 \%$ ), and $4-$ Very high antagonistic activity $(\mathrm{I}>75 \%)$.

After screening, active antagonistic fungi that were rated 4 and 3 were identified. Each isolate was cultured on PDA and identified based on their colony appearance, shape of conidia and conidiophores and branching pattern of phialides. The morphological and microscopic authenticity of the antagonistic fungi was confirmed using different 
identification keys (Watanabe, 2010). Evaluation of most active microbial antagonists based on results obtained after screening against Alternaria solani, Fusarium solani, Colletotrichum lindemuthianum and Rhizoctonia solani was carried out using the same protocol as screening and data was collected over time at two days interval.

\section{Data analysis}

Data on percentage colony diameter inhibition was subjected to analysis of variance using Genstat ${ }^{\circledR}$, Release15.1. Mean separation of the treatments was accomplished using Fisher's protected Least Significant Difference (Steel et al., 1999).

\section{Results and Discussion}

A total of 42 microorganism isolates showed clear zones of inhibition against other microorganisms comprised of fungi, actinomycetes and bacteria of which fungal isolates were the majority. Fungal isolates were 29, bacterial isolates were eight while actinomycetous isolates were five (Tables 1a; 1b). Four microorganism isolates had very high degree of antagonistic activity. The four isolates were from diverse sources including: milking shade mud, nappier grass rhizosphere, compost soil and decomposing wood (Table 1a). The mean percentage growth inhibitions exhibited by the four fungi were $80.4 \%, 79.7 \%, 77.7 \%$ and $77.2 \%$. A total of 12 fungal isolates had high degree of antagonistic activity. All the 16 antagonist microorganism isolates were fungi, with genus Trichoderma being predominant (Table 1a). Other genus included Paecilomyces, Epicoccum, Rhizoctonia, Sepedonium and Gloeosporium.

The antagonistic fungi significantly $(\mathrm{P} \leq$
$0.05)$ reduced colony diameters of all the test plant pathogens. Antagonistic fungi inhibited mycelia growth of the four test plant pathogens by up to $65.8 \%$ and $49 \%$ in experiment one and experiment two, respectively (Tables 2 ). In experiment one, Trichoderma harzianum was the most effective in reducing mycelia growth of test plant pathogens by up to $65.8 \%$ followed by $T$. viride (65.3\%) while least growth inhibition was observed in Sepedonium (37.4\%). The plant pathogens varied in their sensitivity to the different antagonistic fungi. Rhizoctonia solani was the most sensitive while Alternaria solani was the least to the activity of antagonistic fungi. Trichoderma atroviride, Paecilomyces, Trichoderma viride and Trichoderma isolate 3 had the highest biocontrol potency against Alternaria solani, Rhizoctonia solani, Fusarium solani f.sp. phaseoli and Colletotrichum lindumuthianum, respectively. In experiment two, Trichoderma isolate 1 and Trichoderma harzianum were the most effective and showed significant superiority amongst all the antagonistic fungi. Rhizoctonia was least in effectiveness in inhibiting growth of plant fungal pathogens in experiment two compared to experiment one (Tables $2 ; 3$ ).

Microorganisms isolated from local sources had antagonistic activity against Fusarium solani, Colletotrichum lindemuthianum and Rhizoctonia solani. A considerable variation was depicted among, as well as within the fungal, bacterial and actinomycetous antagonists with regard to the colony diameter reduction of the three test pathogens at the ninth DAI. Similar findings were reported by Lahlali and Hijri (2010) that antagonistic fungi had significant antagonistic activity against Rhizoctonia solani in in vitro bioassay. In another study, similar findings were reported on microbial antagonists exhibiting varying degree of 
antagonistic effect against Alternaria sp., and Fusarium oxysporum on PDA medium (Sivanantham et al., 2013).The lumping together of all groups of microorganisms did not yield satisfactory comparative results Some bacteria had pronounced inhibition zones though the diameters of mycelia of test plant pathogens were bigger relative to most fungal isolates hence regarded to have lower antifungal activity. The slight inconsistency of results across the two in vitro bioassays could be attributed to subculturing, storage time in refrigerator of microorganism isolates and further compounded by room temperature fluctuations (Suprapta, 2012). The same variables could have been the cause of shifts in degree of activity among the microorganism isolates. The difference in response to antagonistic activity by the four test pathogens was the result of integrity of the cell wall exhibited by these pathogens.

The different Trichoderma spp. varied in antagonistic activity against different fungi as reported by Muthukumar et al., (2011) Ramzan et al., (2014), Reddy et al., (2014), Belete et al., (2015) and El-Naggar et al., (2016).The results herein were also in line with those by Reddy et al., (2014) who reported that all the isolates of Trichoderma spp. were highly efficacious on the growth of Fusarium oxysporum f. sp. lycopersici, Alternaria solani and others in in vitro bioassay.

Table.1a Growth inhibition of three test plant pathogens by microbial isolates from diverse sources in dual culture test (Bogumil ranking)

\begin{tabular}{|c|c|c|c|c|c|c|c|}
\hline \multirow[t]{2}{*}{ Isolate designation } & \multirow[t]{2}{*}{ Source of collection } & \multirow[t]{2}{*}{ Group } & \multicolumn{3}{|c|}{$\%$ GI at $9^{\text {th }} \mathrm{DAI}$} & \multirow[t]{2}{*}{ Mean } & \multirow{2}{*}{$\begin{array}{l}\text { Bogumil } \\
\text { ranking }\end{array}$} \\
\hline & & & FO & $\mathrm{CO}$ & RO & & \\
\hline FKE3 & Milking shade mud, UK & Fungi & 76.4 & 92.1 & 72.6 & 80.4 & 4 \\
\hline FKF1 & Nappier rhizosphere, UK & Fungi & 76.4 & 92.5 & 70.1 & 79.7 & 4 \\
\hline FS4 & Field Station compost, UK & Fungi & 71.8 & 94.4 & 67.0 & 77.7 & 4 \\
\hline WOOD & Decomposing wood, UK & Fungi & 67.4 & 83.7 & 80.5 & 77.2 & 4 \\
\hline B & Busia soil, PPL & Fungi & 73.3 & 76.4 & 75.0 & 74.9 & 3 \\
\hline WRC(P) & Busia soil, PPL & Fungi & 74.0 & 81.3 & 67.4 & 74.2 & 3 \\
\hline LH1K8D23 & Culture, PPL & Fungi & 67.5 & 79.0 & 70.9 & 72.5 & 3 \\
\hline FKE1 & Milking shade mud, UK & Fungi & 67.4 & 80.2 & 67.1 & 71.6 & 3 \\
\hline FKE2 & Milking shade mud, UK & Fungi & 66.3 & 72.6 & 72.4 & 70.4 & 3 \\
\hline $\operatorname{DRC}(\mathrm{M})$ & Busia soil, PPL & Fungi & 64.1 & 71.0 & 65.3 & 66.8 & 3 \\
\hline LRC(M) & Busia soil, PPL & Fungi & 63.5 & 78.2 & 67.0 & 69.6 & 3 \\
\hline $\operatorname{DRC}(\mathrm{C})$ & Busia soil, PPL & Fungi & 61.9 & 83.3 & 63.2 & 69.5 & 3 \\
\hline A & Busia soil, PPL & Fungi & 60.8 & 74.0 & 72.3 & 69.0 & 3 \\
\hline FKA2 & Animal shade, UK & Fungi & 59.2 & 65.8 & 56.7 & 60.6 & 3 \\
\hline DD2 & Culture, PPL & Fungi & 61.3 & 67.2 & 51.7 & 60.1 & 3 \\
\hline LH1K1N11 & Culture, PPL & Fungi & 62.5 & 63.5 & 54.2 & 60.1 & 3 \\
\hline
\end{tabular}

UK; Upper Kabete Campus, PPL; Plant Pathology Laboratory, GI; Growth inhibition, DAI; Days after inoculation, FO; Fusarium solani, CO; Colletotrichum lindemuthianum and RO; Rhizoctonia solani. $>75 \%$ - Very high and 6075\%- High degree of antagonistic activity. 
Table.1b Inhibition of growth of three test plant pathogens by microbial isolates from diverse sources in dual culture test (Bogumil ranking)

\begin{tabular}{|c|c|c|c|c|c|c|c|}
\hline \multirow[t]{2}{*}{ Isolate designation } & \multirow[t]{2}{*}{ Source of collection } & \multirow[t]{2}{*}{ Group } & \multicolumn{3}{|c|}{$\%$ GI at 9 th DAI } & \multirow[t]{2}{*}{ Mean } & \multirow{2}{*}{$\begin{array}{l}\text { Bogumil } \\
\text { ranking }\end{array}$} \\
\hline & & & $\mathrm{FO}$ & $\mathrm{CO}$ & RO & & \\
\hline FKA3 & Animal shade, UK & Fungi & 62.8 & 60.4 & 54.2 & 59.1 & 2 \\
\hline MAIZE & Maize roots & Fungi & 52.3 & 69.6 & 50.0 & 57.3 & 2 \\
\hline D82 & Culture, PPL & Fungi & 54.6 & 66.7 & 48.8 & 56.7 & 2 \\
\hline BEANFS & Bean roots, UK & Fungi & 55.7 & 60.4 & 52.7 & 56.3 & 2 \\
\hline FS1 & Potato rhizosphere, UK & Bacteria & 55.0 & 67.1 & 45.1 & 55.7 & 2 \\
\hline FKB1 & Bean rhizosphere, UK & Fungi & 53.9 & 57.9 & 50.2 & 54.0 & 2 \\
\hline $\mathrm{WRC}(\mathrm{C})$ & Busia soil, PPL & Fungi & 43.8 & 63.5 & 48.7 & 52.0 & 2 \\
\hline $\mathrm{CN}$ & Compost, Ndumbuini & Fungi & 49.4 & 58.7 & 46.9 & 51.7 & 2 \\
\hline $\mathrm{C}$ & Lantana rhizosphere, UK & Bacteria & 61.4 & 65.6 & 28.2 & 51.7 & 2 \\
\hline $\mathrm{PO}$ & Culture, PPL & Fungi & 50.0 & 55.2 & 46.3 & 50.5 & 2 \\
\hline LH19N1 & Culture, PPL & Fungi & 48.0 & 58.3 & 41.2 & 49.2 & 1 \\
\hline FKB & Bean rhizosphere, UK & Fungi & 42.4 & 59.1 & 45.8 & 49.1 & 1 \\
\hline FKD & Compost, UK & Fungi & 42.4 & 42.5 & 58.7 & 47.9 & 1 \\
\hline LK69 & Busia soil, PPL & Actinomycete & 47.5 & 56.3 & 40.0 & 47.9 & 1 \\
\hline ID3 & Culture, PPL & Fungi & 45.4 & 59.1 & 35.8 & 46.8 & 1 \\
\hline FKB2 & Bean rhizosphere, UK & Bacteria & 36.6 & 57.5 & 39.1 & 44.4 & 1 \\
\hline FSL13 & Silt soil, UK & Bacteria & 43.0 & 63.1 & 26.6 & 44.2 & 1 \\
\hline AS6 & Busia soil, PPL & Actinomycete & 38.5 & 56.3 & 37.3 & 44.0 & 1 \\
\hline DRC(M1) & Busia soil, PPL & Bacteria & 33.9 & 54.0 & 34.2 & 40.7 & 1 \\
\hline LHIK7D22 & Culture, PPL & Fungi & 41.5 & 46.4 & 31.3 & 39.7 & 1 \\
\hline WRC(M) & Busia soil, PPL & Actinomycete & 39.2 & 42.9 & 28.1 & 36.7 & 1 \\
\hline $\mathrm{KSC} 14(\mathrm{~W})$ & Culture, PPL & Bacteria & 29.4 & 44.4 & 32.8 & 35.5 & 1 \\
\hline $\mathrm{KSC} 14$ & Culture, PPL & Actinomycete & 20.6 & 0.0 & 26.9 & 15.8 & 1 \\
\hline AS 7 & Potato rhizosphere, UK & Bacteria & 10.4 & 0.0 & 20.7 & 10.4 & 1 \\
\hline $\mathrm{BN}$ & Bean rhizosphere, UK & Fungi & 5.1 & 0.4 & 17.0 & 7.5 & 1 \\
\hline KSC14 & Field Station compost, UK & Bacteria & 11.0 & 0.0 & 2.3 & 4.4 & 1 \\
\hline
\end{tabular}


Table.2 Percentage colony diameter inhibition of mycelial growth of plant pathogenic fungi by antagonistic fungi, in vitro experiment 1

\begin{tabular}{|c|c|c|c|c|c|}
\hline Antagonist & Alternaria & Rhizoctonia & Fusarium & Colletotrichum & Mean \\
\hline T. harzianum & $56.4 \mathrm{ab}$ & $69.6 \mathrm{ab}$ & $68.9 \mathrm{~b}$ & $68.5 \mathrm{abc}$ & $65.8 \mathrm{a}$ \\
\hline Trichoderma $1^{*}$ & $52.0 \mathrm{bc}$ & $44.5 \mathrm{~g}$ & $55.4 \mathrm{def}$ & $59.8 \mathrm{ef}$ & $52.9 \mathrm{f}$ \\
\hline T. asperellum & $52.1 \mathrm{bc}$ & $68.6 \mathrm{~b}$ & $68.3 \mathrm{~b}$ & $67.1 \mathrm{abcd}$ & $64.0 \mathrm{abc}$ \\
\hline Trichoderma $2 *$ & $48.3 \mathrm{~cd}$ & $65.1 \mathrm{bcd}$ & $57.0 \mathrm{de}$ & $58.0 \mathrm{f}$ & $57.1 \mathrm{e}$ \\
\hline Paecilomyces & $56.7 \mathrm{ab}$ & $74.1 \mathrm{a}$ & $57.5 \mathrm{~d}$ & $64.0 \mathrm{cde}$ & $63.1 \mathrm{c}$ \\
\hline T. pseudokonongii & $43.7 \mathrm{de}$ & $54.3 \mathrm{ef}$ & $55.4 \mathrm{def}$ & $43.3 \mathrm{~h}$ & $49.2 \mathrm{~g}$ \\
\hline T. konongi & $52.8 \mathrm{abc}$ & $69.3 \mathrm{ab}$ & $67.4 \mathrm{bc}$ & 63.4 he & $63.2 \mathrm{bc}$ \\
\hline T. reseei & $52.8 \mathrm{abc}$ & $56.5 \mathrm{e}$ & $54.8 \mathrm{def}$ & $66.1 \mathrm{bcd}$ & $57.5 \mathrm{e}$ \\
\hline T. atroviride & $58.3 \mathrm{a}$ & $67.7 \mathrm{bc}$ & $53.4 \mathrm{ef}$ & $61.2 \mathrm{ef}$ & $60.2 \mathrm{~d}$ \\
\hline T.viride & $48.2 \mathrm{~cd}$ & $70.0 \mathrm{ab}$ & $73.0 \mathrm{a}$ & $70.1 \mathrm{ab}$ & $65.3 \mathrm{ab}$ \\
\hline Trichoderma $3^{*}$ & $55.7 \mathrm{ab}$ & $63.5 \mathrm{~cd}$ & $64.6 \mathrm{c}$ & $71.5 \mathrm{a}$ & $63.8 \mathrm{abc}$ \\
\hline Trichoderma $4 *$ & $43.7 \mathrm{de}$ & $50.0 \mathrm{f}$ & $43.3 \mathrm{~h}$ & $52.4 \mathrm{~g}$ & $47.4 \mathrm{gh}$ \\
\hline Epicoccum & $38.9 \mathrm{e}$ & $42.9 \mathrm{~g}$ & $37.4 \mathrm{i}$ & $36.7 \mathrm{i}$ & $39.0 \mathrm{i}$ \\
\hline Rhizoctonia & $33.5 \mathrm{f}$ & $61.3 \mathrm{~d}$ & $47.7 \mathrm{~g}$ & $43.3 \mathrm{~h}$ & $46.4 \mathrm{~h}$ \\
\hline Sepedonium & $10.9 \mathrm{~g}$ & $53.8 \mathrm{ef}$ & $42.0 \mathrm{~h}$ & $42.8 \mathrm{~h}$ & $37.4 \mathrm{i}$ \\
\hline Gloeosporium & $45.0 \mathrm{~d}$ & $67.2 \mathrm{bc}$ & $53.0 \mathrm{f}$ & $68.2 \mathrm{abc}$ & $57.6 \mathrm{de}$ \\
\hline Control & $0.0 \mathrm{~h}$ & $0.0 \mathrm{~h}$ & $0.0 \mathrm{j}$ & $0.0 \mathrm{j}$ & $0.0 \mathrm{j}$ \\
\hline Mean & 44.0 & 57.6 & 52.9 & 55.1 & 52.4 \\
\hline $\mathrm{LSD}(\mathrm{P} \leq 0.05)$ & 5.3 & 6.0 & 3.6 & 4.2 & 4.8 \\
\hline CV (\%) & 7.2 & 6.2 & 4.1 & 4.6 & 4.7 \\
\hline
\end{tabular}

Means accompanied by different letter(s) in each column are significantly different (Duncan's multiple range test, $\mathrm{P}$ $\leq 0.05)$. 
Table.3 Percentage colony diameter inhibition of mycelial growth of plant pathogenic fungi by antagonistic fungi, in vitro experiment 2

\begin{tabular}{llllll}
\hline Antagonist & Alternaria & Rhizoctonia & Fusarium & Colletotrichum & Mean \\
\hline T. harzianum & $48.1 \mathrm{ab}$ & $38.8 \mathrm{bc}$ & $51.5 \mathrm{~b}$ & $53.3 \mathrm{a}$ & $47.9 \mathrm{ab}$ \\
Trichoderma 1 & $49.5 \mathrm{a}$ & $38.6 \mathrm{bcd}$ & $58.0 \mathrm{a}$ & $49.2 \mathrm{ab}$ & $48.8 \mathrm{a}$ \\
T.asperellum & $46.9 \mathrm{ab}$ & $38.7 \mathrm{bc}$ & $43.2 \mathrm{c}$ & $53.4 \mathrm{a}$ & $45.6 \mathrm{~b}$ \\
Trichoderma 2 & $48.3 \mathrm{ab}$ & $35.5 \mathrm{bcde}$ & $52.3 \mathrm{~b}$ & $52.0 \mathrm{a}$ & $47.0 \mathrm{ab}$ \\
Paecilomyces & $51.5 \mathrm{a}$ & $51.2 \mathrm{a}$ & $43.8 \mathrm{c}$ & $46.7 \mathrm{~b}$ & $48.3 \mathrm{a}$ \\
T. pseudokonongii & $37.7 \mathrm{~d}$ & $35.5 \mathrm{bcde}$ & $42.7 \mathrm{~cd}$ & $38.1 \mathrm{cde}$ & $38.5 \mathrm{de}$ \\
T. konongii & $39.0 \mathrm{~cd}$ & $31.8 \mathrm{ef}$ & $42.2 \mathrm{~cd}$ & $36.6 \mathrm{cdef}$ & $37.4 \mathrm{de}$ \\
T. reseei & $38.9 \mathrm{~cd}$ & $36.3 \mathrm{bcde}$ & $39.2 \mathrm{cde}$ & $32.2 \mathrm{f}$ & $36.6 \mathrm{e}$ \\
T. atroviride & $38.6 \mathrm{~cd}$ & $32.8 \mathrm{cdef}$ & $37.0 \mathrm{de}$ & $39.7 \mathrm{~cd}$ & $37.0 \mathrm{de}$ \\
T.viride & $34.6 \mathrm{~d}$ & $40.2 \mathrm{~b}$ & $40.8 \mathrm{cde}$ & $38.3 \mathrm{cde}$ & $38.5 \mathrm{de}$ \\
Trichoderma 3 & $37.5 \mathrm{~d}$ & $40.4 \mathrm{~b}$ & $35.4 \mathrm{e}$ & $39.1 \mathrm{~cd}$ & $38.1 \mathrm{de}$ \\
Trichoderma 4 & $43.7 \mathrm{bc}$ & $39.7 \mathrm{~b}$ & $44.7 \mathrm{c}$ & $40.6 \mathrm{c}$ & $42.2 \mathrm{c}$ \\
Epicoccum & $28.6 \mathrm{e}$ & $28.2 \mathrm{f}$ & $29.7 \mathrm{f}$ & $32.8 \mathrm{ef}$ & $29.8 \mathrm{f}$ \\
Rhizoctonia & $16.9 \mathrm{f}$ & $7.4 \mathrm{~h}$ & $16.0 \mathrm{~g}$ & $10.8 \mathrm{~h}$ & $12.7 \mathrm{~h}$ \\
Sepedonium & $17.6 \mathrm{f}$ & $21.0 \mathrm{~g}$ & $30.1 \mathrm{f}$ & $16.6 \mathrm{~g}$ & $21.3 \mathrm{~g}$ \\
Gloeosporium & $38.8 \mathrm{~cd}$ & $32.7 \mathrm{def}$ & $52.2 \mathrm{~b}$ & $34.6 \mathrm{def}$ & $39.6 \mathrm{~d}$ \\
Control & $0.0 \mathrm{~g}$ & $0.0 \mathrm{i}$ & $0.0 \mathrm{~h}$ & $0.0 \mathrm{i}$ & $0.0 \mathrm{i}$ \\
\hline Mean & 36.2 & 32.3 & 38.7 & 36.1 & 35.9 \\
LSD ( P $\leq 0.05$ ) & 5.6 & 5.7 & 5.9 & 5.0 & 5.6 \\
CV ( \% ) & 9.4 & 10.6 & 9.3 & 8.4 & 8.7 \\
\hline Ter & & & &
\end{tabular}

Means accompanied by different letter(s) in each column are significantly different (Duncan's multiple range test, $\mathrm{P}$ $\leq 0.05$ ).

Trichoderma harzianum had the highest antagonistic activity and this was in line with the findings by Soliman et al., (2015) who reported that among the antagonists tested, T. harzianum highly retarded the growth of Botrytis cinerea. Findings in the current study were consistent with findings by Muthukumar et al., (2011) in regard to Trichoderma spp. antagonism. Contrary findings to our study were reported by
(Otadoh et al., 2011) that $T$. reesei had the highest inhibitory effect on mycelia growth of Fusarium oxysporum f. sp. Phaseoli among all Trichoderma spp. tested. Findings by Mahmoud (2015) were not in line with our findings during the first bioassay of $T$. harzianum against species of Fusarium and Rhizoctonia since Fusarium sp. was the most sensitive. Antifungal activity of Trichoderma is attributed to various 
mechanisms key among them being antibiosis and competition. In addition studies by Muthukumar et al., (2011) and Hermosa et al., (2000), indicate that Trichoderma spp. produce enzymes, volatile and non-volatile metabolites that degrade cell walls of pathogens and inhibit mycelia growth.

Other species that had antagonistic activity against the test pathogens included Epicoccum, Rhizoctonia, Sepedonium and Gloeosporium. The efficacy of Epicoccum in inhibiting mycelial growth of plant pathogens may be due to its production of numerous antifungal compounds such as flavipin (Madrigal and Melgarejo, 1994). Paecilomyces in this study showed profound effect of suppressing the four test pathogens and corroborates with the results reported by Ramzan et al., (2014). In 2015, Perveen et al., reported similar findings that Paecilomyces sp. was highly efficacious against Sclerotium rolfsii and Pythium aphanidermatum in dual culture bioassays. Biocontrol potency of Paecilomyces can be attributed to production of active metabolites that inhibit growth of other microorganisms.

Another attribute of Paecilomyces is the capability to colonise the agar surface much faster compared to the pathogen (Muhammad and Amusa, 2003). This status of microorganism antagonist-phytopathogen specificity may be as a result of differences in levels of hydrolytic enzymes produced by each species or isolate when they attack the mycelia of the pathogens (Reddy et al., 2014). This study advocates that hyphal interaction and parasitism are subsets of mycoparasitism that were exhibited by antagonistic fungi (Hermosa et al., 2000; Howell, 2003; Reddy et al., 2014; Belete et al., 2015).

In conclusion, the results obtained from the laboratory studies illustrate how the exploitation of local environment in search of microbial antagonists against pytopathogenic fungi in vegetables is promising. Use of antagonistic fungi in management of fungal diseases was effective under in vitro conditions. The findings showed that all the antagonistic fungi have antifungal effect on the mycelia growth of pytopathogens with Trichoderma spp. and Paecilomyces giving more promising results than other isolates. Trichoderma spp. and Paecilomyces could be used for management of fungal diseases in snap beans grown by farmers in Kenya. Antagonistic fungi are potentially effective in management of diseases in snap beans in fields hence more studies on efficacy should be conducted. Further work on continued exploitation of local environment in search for more microbial antagonists should be undertaken. Further research to determine active ingredients of antagonistic fungi and their formulations may be of high priority in enhancing their effectiveness in field. Intensive research on integrating biocontrol agents with conventional methods to manage diseases in snap beans should be emphasized to reduce use of synthetic pesticides.

\section{Acknowledgement}

The Regional Universities Forum for Capacity Building in Agriculture (RUFORUM) is gratefully acknowledged for funding this study (Grant No: RU 2014 GRG-096).

\section{References}

Belete, E., Ayalew, A., Ahmed S. 2015. Evaluation of local isolates of Trichoderma spp. against black root rot (Fusarium solani) on Faba bean. $J$. Plant Pathol. Microbiol., 6: 279. 
Bogumił, A., Paszt, L.S., Lisek, A., Trzciński, P. and Harbuzov. A., 2013.Identification of new

Trichoderma strains with antagonistic activity against Botrytis cinerea. Polish Society for Horticultural Sci., 25(2): 123-132.

El-Naggar, M.A., Abouleid, H.Z., El-Deeb, H.M., Abd-El-Kareem, F., and Elshahawy, I.E., 2016. Biological control of potato late blight by means of induction systemic resistance and antagonism. Res. J. Pharmaceutical, Biol. Chem. Sci., 7(1): 1338-1348.

Fening, K.O., Adama, I., and Tegbe, R.E., 2014. On-farm evaluation of homemade pepper extract in the management of pests of cabbage, Brassica oleraceae L., and French beans, Phaseolus vulgaris L., in two agro-ecological zones in Ghana. African Entomol., 22(3): 552-560.

Figueirêdo, G.S., Figueirêdo, L.C., Cavalcanti, F.C.N., Santos, A.C., Costa, A.F., and Oliveira, N.T., 2010. Biological and chemical control of Sclerotinia sclerotiorum using Trichoderma spp. and Ulocladium atrum and pathogenicity to bean plants. Brazilian Archives of Biol. Technol., 53(1): 1-9.

Howell, C.R., 2003. Mechanisms employed by Trichoderma species in the biological control of plant diseases: The history and evolution of current concepts. Plant Dis., 87: 4-10.

Infonet-Biovision, $2015 . \quad$ Infonet-

Biovisionhttp://www.infonet-

biovision.org/default/ct/118/crops

(Accessed on 27/ 01/ 2015).

Lahlali, R., and Hijri, M., 2010. Screening, identification and evaluation of potential biocontrol fungal endophytes against Rhizoctonia solaniAG3 on potato plants. Federation of European Microbiol. Societies Microbiology
Paper, 31: 152-159.

Madrigal, C., Melgare, P., 1994. Morphological effects of Epicoccum nigrum and its antibiotic flavipin on Monilia laxa. Canadian J. Bot., 73: 425-431.

Mahmoud, M.A. 2015. Efficiency of some bioagents and Nemastop compound in controlling damping off and root rot diseases on peanut plants. Int. J. Adv. Res. Biol. Sci., 2(11): 77-86.

Mohammed, A. 2013. An overview of distribution, biology and the management of common bean anthracnose. J. Plant Pathol. Microbiol., 4: 193.

Mulanya, M.M., Kimani, P.M., and Narla, R.D., 2014. Selection for multiple disease resistance in bush snap bean lines developed in Kenya Fourth RUFORUM Biennial Conference, Maputo, Mozambique.

Muthukumar, A., Eswaran, A., and Sanjeevkumas, K. 2011. Exploitation of Trichoderma species on the growth of Pythium aphanidermatum in chilli. Brazilian J. Microbiol., 42: 1598-1607.

Nyasetia, D.M.S. 2011. Antifungal activity of selected crude plant extracts on bean rust (Uromyces appendiculatus) and their effects on physiological activities of French beans. M.Sc. Thesis, Jomo Kenyatta University of Agriculture and Technology, Kenya.

Omar, A.M., and Ahmed, A.I.S., 2014. Antagonistic and inhibitory effect of some plant rhizo-bacteria against different Fusarium isolates on Salvia officinalis. American-Eurasian J. Agriculture and Environ. Sci., 14(12): 1437-1446.

Otadoh, J.A., Okoth, S.A., Ochanda, J., and Kahindi, J.P., 2011. Assessment of Trichoderma isolates for virulence efficacy on Fusarium oxysporum f.sp. phaseoli. Tropical and Subtropical 
Agroecosystems, 13: $99-107$.

Ouma, B., Muthomi, J., Nderitu, J., and Toroitich, F., 2014. Management of trips in French beans by integrating biological and synthetic pesticides in conventional spray regimes. $J$. Renewable Agriculture, 2(2): 27-37.

Palate, S.S., and Mukadam, D.S., 2011. Management of plant pathogenic fungi by using Trichoderma. Bioscience Discovery, 2(1): 36-37.

Perveen, Z., Ramzan, N., Nayara, N., Rajpuit, A.Q., and Shahzad, S., 2015. In vitro evaluation of biocontrol potential of Paecilomyces species against Sclerotium rolfsii and Pythium aphanidermatum. Int. J. Biol. Biotechnol., 12(3): 407-411.

Ramzan, N., Nayara, N., and Shahzad, S., 2014. Inhibition of in vitro growth of soil-borne pathogens by compostinhabiting indigenous bacteria and fungi. Pakistan J. Bot., 46(3): 10931099.

Reddy, B.N., Saritha, K.V., and Hindumathi,
A., 2014. In vitro screening for antagonistic potential of seven species of Trichoderma against different plant pathogenic fungi. Res. J. Biol., 2: $29-$ 36 .

Sivanantham, T., Rasaiyah, V., Satkunanathan, N., and Thavaranjit, A.C., 2013.In vitro screening of antagonistic effect of soil borne bacteria on some selected phytopathogenic fungi. Archives of Applied Science Res., 5 (1):1-4.

Srinivasan, R., 2012. Integrating biopesticides in pest management strategies for tropical vegetable production. J. Biopesticides, 5: 36-45.

Suprapta, D.N., 2012. Potential of microbial antagonists as biocontrol agents against plant fungal pathogens. $J$. ISSAAS, 18(2): 1-8.

Watanabe, T. 2010. Pictorial atlas of soil and seed fungi: morphologies of cultured fungi and key to species. Third edition. Taylor and Francis Group, LLC.

\section{How to cite this article:}

Alex M. Fulano, James W. Muthomi, John M. Wagacha and Agnes W. Mwang'ombe. 2016. Antifungal Activity of Local Microbial Isolates against Snap Bean Pathogens. Int.J.Curr.Microbiol.App.Sci. 5(12): 112-122. doi: http://dx.doi.org/10.20546/ijcmas.2016.512.013 